\title{
Aquatic Plants for Acid Mine Drainage Remediation in Simulated Wetland Systems
}

\author{
Ali Munawar*), Farkhruddin Okte Leitu, and Hendri Bustamam \\ Faculty of Agriculture, University of Bengkulu, Bengkulu 38371 \\ Diterima 14-04-2010 Disetujui 20-04-2011
}

\begin{abstract}
Aquatic plant is an important component of a constructed wetland system for treating acid mine drainage (AMD). This study was conducted to investigate the remediation effects of planting three aquatic plants species on AMD quality in simulated wetland systems. Simulated wetland systems were constructed using 10-L plastic containers as growth media comprising mixed-organic substrates and aquatic plant species as planting treatments. The treatments involved individual plantings with Fimbristilys hispidula (Vahl) Konth, Mariscus compactus (Retz) Druce, and Typha angustifolia L., and mixed-planting with a combined three-plant species. As the control was the unplanted media. The plants were continuously flooded with very acidic AMD collected from a mine pit in PT Tambang Batubara Bukit Asam, South Sumatra. During the experiment, the acidity (pH), oxidation reduction potential (Eh), and electrical conductivity (EC) of the flooding AMD were measured after 24 hours of the flooding, and then biweekly until the plants entered their reproductive stage. To estimate Fe removed by plants, AMD samples were taken from both planted and unplanted systems for total dissolved Fe analyses. The data revealed some remediation effects of planting aquatic plants on AMD in the wetland treatment systems. The presence of plants in the wetland system appeared to induce oxygen diffusion to surrounding roots, which might result in Fe precipitation on root surface. Although no differences among planting treatments, Fe removals by plants highly correlated $\left(R^{2}=0.92\right)$ with the production of plant biomass.
\end{abstract}

Keywords: acid mine drainage, aquatic plants, remediation, wetland

\section{INTRODUCTION}

More than two decades, constructed wetland has become an alternative technology for acid mine drainage (AMD) treatment (Nyquist \& Greger, 2003; Sheoran, 2006; Maine et al., 2007). This passive treatment removes contaminants from AMD through complex mechanisms, involving interacting physical, chemical, and biological processes. A number of mechanisms have been reported to be associated with plants, as important component of treatment wetlands (Brinx, 1997; Betty, 2003; Kamal et al., 2004; Nyquist \& Greger, 2003; Scholz, 2003; Sheoran, 2006).

Although the roles of plants in a treatment wetland have been generally considered minor (Batty, 2003), a number of works have shown otherwise. Bose et al., (2008), stated that plants play an important role in wetland geochemistry due to their active/passive transport of elements. Metal accumulation by various wetland plants has been documented by other investigators. A study by Cheng et al., (2002),

\footnotetext{
*Telp: 081227757795

Email: a.munawar008@gmail.com
}

found that Cyperus alternifolius and Vallarsia removed one-third of $\mathrm{Cd}, \mathrm{Cu}, \mathrm{Pb}, \mathrm{Mn}$, and $\mathrm{Zn}$ from a wetland. Similarly Kamal et al., (2004), reported that Myriophyllum aquaticum (parrot feather), Mentha aquatic (water mint), and Ludwigiana palustris (creeping primrose) removed $94.36-99.35 \%$ of $\mathrm{Fe}, 17-40 \%$ of $\mathrm{Zn}$, $39-60 \%$ of $\mathrm{Cu}$, and $90.05-93.36 \%$ of $\mathrm{Hg}$ from a simulated wetland. Emergent species Typha domingensis (cattail) and floating species Lemna minor removed $\mathrm{Cd}$ and $\mathrm{Pb}$ up to $50 \%$ and $45-51 \%$, respectively, from wetland microcosms (Weiss et al., 2006). Paredes et al., (2007), reported that more $\mathrm{Cr}$ and $\mathrm{Zn}$ were removed from small-scale model wetlands planted with Typha latifolia than from the unplanted.

Apart from the role of aquatic plants as metal accumulator described above, there are several other important functions of plants in a wetland system. The plants stablilize the surface of the beds, provide good conditions for physical filtration, prevent vertical flow systems from clogging, insulate against frost during winter, and provide a huge surface area for attached microbial growth (Skousen \& Ziemkiewicz, 1996; Barry, 
2003). Plants increase residence time of the incoming water and thereby increase metal retention within the wetland (Nyquist \& Greger, 2003). Plant-mediated transfer of oxygen to the rhizosphere by leakage from roots increases aerobic degradation of organic matter. Growing plants are also important source of $C$ for providing a food source for the bacteria that are responsible for sulfate reduction, resulting in the immobilization of metals (Skousen \& Ziemkiewicz, 1996; Batty, 2003). The vegetated wetlands have additional site-specific values by providing habitats for wildlife and making wastewater treatment systems aesthetically pleasing (Brink, 1994; Skousen \& Ziemkiewicz, 1996; Batty, 2003).

Limited plant species in Indonesia have been studied, particularly for the purpose of acid mine drainage remediation in a wetland system. An initial work by Juhaeti et al., (2005), reported that Mikania cordata (Burmf,) B. L. Robinson and Fimbristlys milace (L.) Vahl were tolerant and absorbed large amounts of $\mathrm{Pb}$ from alkaline tailings from gold mine in Bogor. In a previous study using 15 aquatic plant species collected from area of coal mine site of PT Tambang Bukit Asam (PERSERO) Tbk, Tanjung Enim, South Sumatra, the first author found four species [(Cyperus tenuiculmis Boeck., Elaeocharis dulcis (Burmf) Henschel, Fimbristilys hispidula (Vahl) Konth, Mariscus compactus (Retz) Druce, and Typha angustifolia L.] grew well in media flooded with very poor AMD, which had $\mathrm{pH}$ of 2.8 and relatively high dissolved Fe concentration (Munawar, 2007). Therefore, further study on the use of aquatic plants in a treatment wetland is needed.

This study was intended to investigate the remediation effects of planting three aquatic plants species [Fimbristiyis hispidula (Vahl) Konth, Mariscus compactus (Retz) Druce, and Typha angustifolia L.] on AMD quality in simulating wetland treatment systems.

\section{MATERIALS AND METHODS}

This study was conducted in a wire house belongs to the Faculty of Agriculture, University of Bengkulu. A bench-scale wetland cell simulation was constructed using $10 \mathrm{~L}$-plastic containers, organic substrate mixtures of $25 \%$ chicken manure $+25 \%$ sludge $+50 \%$ bark as growth media, three aquatic plants species, and poor AMD. The chicken manure was obtained from local farmers in Bengkulu, while sludge and bark were supplied by a pulp and paper industry (PT Tanjung Enim
Lestari), Tanjung Enim, South Sumatra. All organic materials were passed through $5 \mathrm{~mm}$ sieve to obtain uniform materials, mixed in their respective portions, and air-dried. The growth media were obtained by weighing $4 \mathrm{~kg}$ of the organic mixtures, and then were added with $0.4 \mathrm{~kg}$ of soil mud for media stabilization. The aquatic plants comprising Fimbristilys hispidula (Vahl) Konth, Mariscus compactus (Retz) Druce, and Typha angustifolia L. were collected from a coal mine site of PT Tambang Batubara Bukit Asam (Tbk), Tanjung Enim, South Sumatra. Whereas AMD were taken from Pit 1 at Banko Barat Mine Unit of PT Tambang Batubara Bukit Asam (Tbk.), Tanjung Enim, South Sumatra. The compositions of the AMD averaged $3.6 \mathrm{mg} \mathrm{L}^{-1}$ dissolved $\mathrm{Fe}$, electrical conductivity $(\mathrm{EC}) 1121 \mu \mathrm{S} \mathrm{cm}^{-1}$, reductionoxidation (redox) potential (Eh) $503 \mathrm{mV}$, and pH 2.80.

The experiment was designed in a Completely Randomized Design (CRD) with aquatic plant planting as the single factor, involving four planting treatments. These treatments were: (1) planting with Fimbristilys hispidula (Vahl) Konth, (2) planting with Mariscus compactus (Retz) Druce, (3) planting with Typha angustifolia L, and (4) mixed-planting with the combined three plants species. The growth media were incubated with AMD for two weeks and then uniform plant seedlings of each species were transplanted in to the growth media. During the experiment the media were continuously flooded at $3-5 \mathrm{~cm}$ depth. After plants were better established, the media were flooded with AMD at a constant depth at $3-5 \mathrm{~cm}$. As the treatment controls were unplanted growth media. All treatments were replicated four times and each replication consisted of two seed-lots, resulting in 40 experimental units.

During the experiment $\mathrm{pH}$, Eh, and $\mathrm{EC}$ of the flooding AMD were measured directly in the containers, respectively using a $\mathrm{pH}$ meter, lithium electrode-provided $\mathrm{pH} / \mathrm{mV}$ meter, and conductivity meter. The first measurement was conducted at 24 hours after media were incubated, and the subsequent measurements were then measured biweekly until most plants entered the flowering stage (98 days). Prior to plant harvest, $200 \mathrm{ml}$ of AMD samples were carefully taken using a clean syringe and sieved into plastic bottles and added with $2 \mathrm{ml}$ concentrated $\mathrm{HNO}_{3}$ for total dissolved $\mathrm{Fe}$ analyses. Dissolved Fe concentrations were analyzed using Atomic Absorption Spectrophotometer (AAS). The data of the total dissolved $\mathrm{Fe}$ were used to estimate the amounts of Fe removed by plants, by subtracting 
the concentrations of the dissolved Fe remaining in the unplanted media (control) by those in planted media. The whole plants were harvested and then dried in the oven of $80^{\circ} \mathrm{C}$ until constant weight.

The collected data were statistically analyzed using Analysis of Variance (ANOVA) test. If the treatments showed significant differences, their mean treatment effects were tested using Least Significant Difference (LSD) test at á $=0.05$.

\section{RESULTS AND DISCUSSIONS}

Acid mine drainage $\mathrm{pH}$. Overall $\mathrm{pH}$ values of the $A M D$ in all planting treatments and the control during the experiment were much higher than its original $\mathrm{pH}$ (2.80) as presented in Figure 1a. This means that the substrates in the growth media had played important role in raising the $\mathrm{pH}$, regardless the planting treatments. Such observations have been reported by various studies (Waybrant et al., 1998; Gibert et al., 2004; Zagury et al., 2006; Sheoran, 2006; Munawar \& Riwandi, 2010). Alkaline manure and sludge contained in the growth media might have contributed their alkalinity to the system. Besides, the organic media could also have provided sources of $C$ for sulfatereducing bacteria (SRB) to develop, resulting in sulfate reduction to sulfides which then reduced acidity and hence increased alkalinity $(\mathrm{pH})$. This agrees with a study by Sheoran (2006), who found significant $\mathrm{pH}$ increases (from around 3 to more than 7 in a wetland system using wood chips and goat manure. In a previous study we also found that organic wastes containing high alkalinity (high $\mathrm{pH}$ ) and nutrient concentrations (chicken manure) improved AMD quality, through increasing its $\mathrm{pH}$ above 6 (Munawar \& Riwandi, 2010). Drastic increase from $\mathrm{pH} 2.8$ of the original AMD to more than 6 occurred 24 hours after treatment application. Thereafter, the $\mathrm{pH}$ of AMD under all planting treatments was relatively constant at levels between 6 and 7 until the end of the experiment.

Our statistical analysis $(P<0.05)$ found that the significant effects of overall planting treatments occurred at 24 hours ( $1^{\text {st }}$ day) and on $56^{\text {th }}$ day after planting. After 24 hours the $\mathrm{pH}$ values of $\mathrm{AMD}$ in all the planted media (pH 6.15-6.25) were significantly higher than in the unplanted media ( $\mathrm{pH}$ 5.97), although there were no significant differences among the planting treatments. Similar results were reported by Sheoran (2006), who found $\mathrm{pH}$ increases from about 3 to more than 7 after 24 hours of planting three plant species (Typha angustifolia, Desmostachya bipinnata, and Sacharum bengalense) in media consisting of $75 \%$ soil, $20 \%$ powdered goat manure, and $5 \%$ wood shavings. $\mathrm{He}$ attributed these increases to the sulfide precipitation, generating alkalinity in the system.

On the $56^{\text {th }}$ day, however, there were larger variations of the treatment effects. The AMD under Fimbristilys hispidula had the highest $\mathrm{pH}$ (6.61), but not different from Typha angustifolia; while under Mariscus compactus the AMD had the lowest pH (6.11) although not different from both the mixed planting (6.25) and control (6.15).

Redox Potential. Redox potential (Eh) data are given in Figure 1b. The Eh values of the media varied among planting treatments on the first to $14^{\text {th }}$ day after

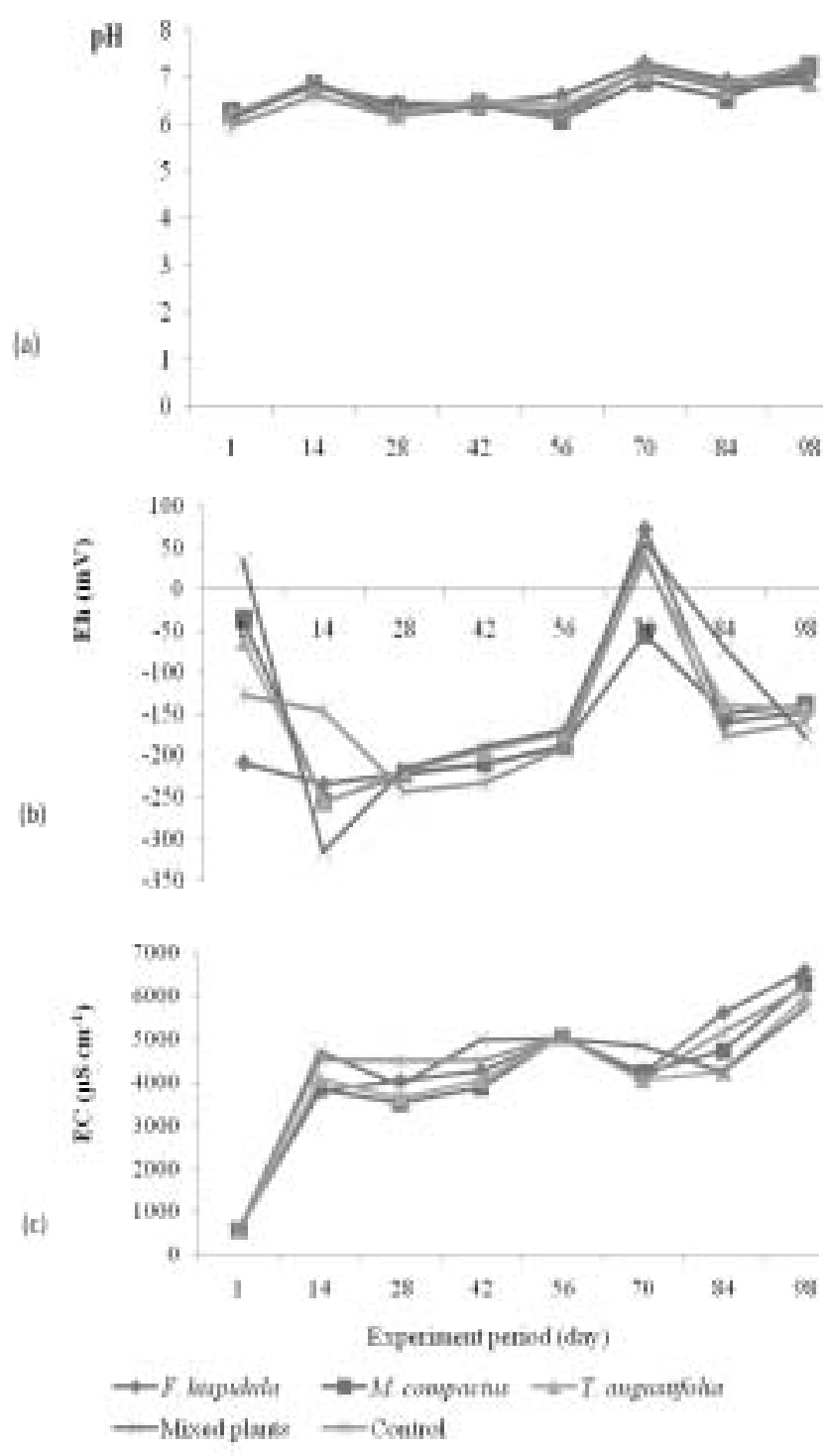

Figue 1 Charges in (a) pH, (b) Eh, anil (c) EC of the AMD inning the experiment 
planting. On the first day, the condition under $F$. hispidula was most reduced (-208 $\mathrm{mV})$, whereas under mixed plants was most oxidized $(35 \mathrm{mV})$. Although statistically not different on the $14^{\text {th }}$ day, however, all media became more reduced, with most reduced condition $(-316 \mathrm{mV})$ in the mixed plants and least reduced $(-146 \mathrm{mV})$ under control. Larger Eh variation in the early period (up to 14th day) was common phenomenon. Unstable conditions occurred before the equilibrium was achieved, thereafter the variations decreased. After $28^{\text {th }}$ day the redox potentials in all treatments increased over time, and the control tended to be most reduced. Statistical analyses showed that on the $42^{\text {nd }}$ day, the unplanted media was most reduced, although not significantly different from those under mixed-planting and F. hispidula planting. The most reduced condition in the unplanted media developed until the end of the experiment. The unplanted media were relatively undisturbed system during the experiment; thus, there was practically no oxygen diffusion to the system. On the other hand, oxygen diffusion might have occurred in the root-soil interface in the planted media. After $56^{\text {th }}$ day the Eh drastically increased until the $70^{\text {th }}$ day, and then significantly declined.

The overall development of reduced conditions during most of the experiment period was probably due to increase in microbial activity as the organic matter decomposed, consuming significant amounts of oxygen. Such reduced conditions, provided with high C source availability, had likely enhanced sulfatereducing bacteria to develop, as have mentioned early, resulting in insoluble compounds such as Fe-sulfides. Although Fe-sulfide was not measured in this research, the black color development on the surface of growth media might indicate Fe-sulfide formation. It has been reported that organic substance from death aquatic plants in a wetland system could provide $\mathrm{C}$ source for sulfate-reducing bacteria, resulting in metal immobilization (Batty, 2003). Despite fluctuations of redox conditions (Eh) during the experiment, statistical analyses showed that Eh differences only occurred on the first day and $42^{\text {nd }}$ day, and in general there were no significant differences in Eh among planting treatments,

Electrical Conductivity. Electrical conductivity (EC) describes the total ionic strength of the AMD. The $E C$ values of $A M D$ in both planted and unplanted media were much higher than its original EC $\left(1121 \mu \mathrm{S} \mathrm{cm}^{-1}\right)$ after $14^{\text {th }}$ day or planting time, and continuously increased until the end of the experiment (Figure 1c). This indicates that there had been ions or dissolved solids released into the water as the organic media and/or death plants was decaying, increasing the dissolved ions content and hence EC until the end of the experiment. Very high EC could potentially be detrimental to root growth of most plants. However, all plants species used in the experiment appeared to be tolerant to high EC. Similar observations had been reported by other investigators using different aquatic plants. Maine et al., (2007), found Eichhornia crassipes and Typha domingensis tolerant to as high $4000 \mu \mathrm{S}$ $\mathrm{cm}^{-1} \mathrm{EC}$ in a treatment wetland. Although the effects of planting treatments on $\mathrm{EC}$ seemed to be less than did the organic media, EC slightly varied within $14^{\text {th }}$ day and $56^{\text {th }}$ day showing the influence of the planting treatments. The AMD in the planted media with species of larger dry mater, M. compactus and T. angustifolia, tended to have lower EC, whereas in the absence of growing plants (control) it remained relatively high. Lower EC under the planted media was probably resulted from nutrient uptake by plants, reducing salt concentration in the media.

Iron (Fe) Removals and Production of Plant Biomass. The Fe removal from AMD by plants was calculated by subtracting the concentrations of the total dissolved Fe which remained in the unplanted media

Table 1. Total dissolved Fe in AMD, Fe removed by plants, and total plant dry matter as affected by planting treatments

\begin{tabular}{|c|c|c|c|c|}
\hline $\begin{array}{l}\text { Planting } \\
\text { treatments }\end{array}$ & $\begin{array}{l}\text { Total dissolved Fe } \\
\left(\mathrm{mg} \mathrm{I}^{-1}\right)^{\hat{1}}\end{array}$ & $\begin{array}{l}\text { Total Fe removed by plants } \\
\qquad\left(\mathrm{mg} \mathrm{l}^{-1}\right)^{\left.\hat{i}^{*}\right)}\end{array}$ & $\begin{array}{l}\text { Total Fe removed by plants } \\
(\%)^{\left.\mid{ }^{* *}\right)}\end{array}$ & $\begin{array}{c}\text { Total plant dry matter } \\
(\mathrm{g})\end{array}$ \\
\hline F. hispidula & $3.50 \mathrm{a}$ & $0.91 \mathrm{a}$ & $20.41 \mathrm{a}$ & $3.89 \mathrm{c}$ \\
\hline M. compactus & $2.77 \mathrm{a}$ & $1.64 \mathrm{a}$ & $37.19 \mathrm{a}$ & $28.95 a b$ \\
\hline T. angustifolia & $3.80 \mathrm{a}$ & $0.61 \mathrm{a}$ & $14.29 \mathrm{a}$ & $10.82 \mathrm{bc}$ \\
\hline Mixed-plants & $2.11 \mathrm{a}$ & $2.30 \mathrm{a}$ & $52.15 \mathrm{a}$ & $51.17 \mathrm{a}$ \\
\hline Unplanted (Control) & $4.41 \mathrm{a}$ & - & & - \\
\hline
\end{tabular}

\footnotetext{
i Values in the same column followed by same letters were not significantly different $(P<0.05)$

$\left.{ }^{*}\right)$ Total Fe removed by plants = Total Dissolved Fe in the Control - Total Dissolved Fe in Planting Treatments

${ }^{* *}$ ) Total Fe removed by plants $=$ Total Fe removed by plants/Total dissolved Fe in the control
} 
(control) with those in the planted media, as shown in Table 1. Although statistically not different $(P<0.05)$ among planting treatments, the total dissolved $\mathrm{Fe}$ in the unplanted media at the end of the experiment tended to be higher than under planted media, and the lowest concentration occurred in the mixed-planting. This means mixed-plants tended to remove more Fe from the AMD, followed by $M$. compactus, $F$ hispidula, and $T$. angustifolia. The amounts of Fe removed from AMD well correlated $\left(R^{2}=0.92\right)$ with the productions of plant biomass (Figure 2). The larger the dry matter production of the plants, the higher the plant could remove Fe from the AMD. There are at least two reasons which could explain such a relationship: (i) $\mathrm{Fe}$ is an essential plant nutrient, and therefore plants with higher biomass absorbed more Fe for their growth; and (ii) higher total root biomass of plants had provided larger sites in their root systems for $\mathrm{Fe}$ ions adsorption and formation of Fe precipitates. Although no quantitative data on both plant Fe uptake and retained Fe on the roots surface are available, these results indicate that growing plants in a wetland system could contribute to the removals of the dissolved Fe from AMD, as has also been suggested by other previous investigations (Sheoran, 2004; Ye et al., 2001).

\section{CONCLUSIONS}

Planting aquatic plants in simulating wetland systems showed remediation effects on the AMD during the experiment. The presence of the plants induced oxidizing condition (higher Eh values) of AMD-flooded media. Aquatic plants removed some amounts of $\mathrm{Fe}$ from the AMD, corresponding with plant biomass production. Increase in Fe uptake and larger sites for metal immobilization could be two mechanisms of $\mathrm{Fe}$ removals from $A M D$ by the aquatic plants.

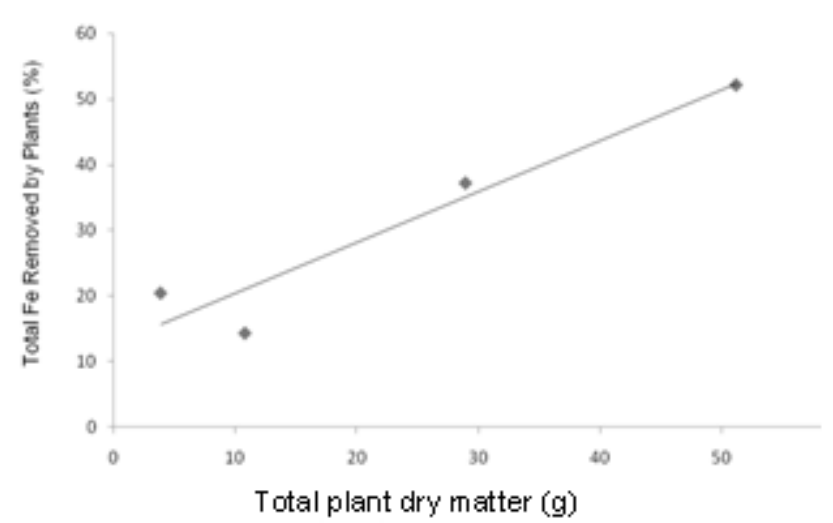

Figure 2. Relationship between total Fe removed by plants and total plant dry matter
The implications of the results of this study are (1) plants with high biomass productions are preferred, and (2) aquatic plants are more suitable for removing Fe from AMD under more oxidized conditions, such as in an aerobic wetland.

\section{ACKNOWLEDMENT}

The authors thank the Office of the Ministry of Research and Technology for partly supporting this study under the Riset Unggulan Terpadu (RUT) 2005; and PT Tanjung Enim Lestari and PT Batubara Bukit Asam (PERSERO) Tbk, Tanjung Enim, South Sumatra for providing materials used in this research.

\section{REFFERENCES}

Baso, S., Jarutti, V. \& Ramanathan, A.L. 2008. Metal uptake and transport by Typha angustata L. grown on metal contaminated waste amended soil: An implication of phytoremediation. Geoderma 145: 136-142.

Batty, L.C. 2003. Wetland plants-more than just a pretty face? Land Contamination and Reclamation, 11(2): 173-180.

Brix, H. 1997. Functions of macrophytes in constructed wetlands. Water Science Technol 29: 71-78.

Cheng, S., Grosse, W., Karrenbrock, F. \& Thoennessen, M. 2002. Efficiency of constructed wetlands in decontamination of water polluted by heavy metals. Ecological Eng 18(3): 317-325.

Gibert, O., de Pablo, P., Cortina, J.L. \& Ayora, C. 2004. Chemical characterisation of natural organic substrates for biological mitigation of acid mine drainage. Water Res 38: 4186-4196.

Juhaeti, T., Syarif, F. \& Hidayati, N. 2005. Inventarisasi tumbuhan potensial untuk fitoremediasi lahan dan air terdegradasi penambangan emas. Biodiversitas 6(1): 31-33.

Kamal, M., Ghaly, A.E., Mahmoud, N. \& Co^te, R. 2004. Phytoaccumulation of heavy metals by aquatic plants. Environment International 29: 1029-1039

Maine, M.A., Su-ne, N., Hadad, H., Sanchez, G. \& Bonetto, C. 2007. Influence of vegetation on the removal of heavy metals and nutrients in a constructed wetland. Journal of Environmental Management xx, 1-9.

Munawar, A. 2007. Pemanfaatan sumberdaya biologis local untuk pengendalian pasif air asam tambang: Lahan Basah Buatan. Jurnal IImu Tanah dan Lingkungan 7(1): 31-42.

Munawar, A. \& Riwandi. 2010. Chemical characteristics of organic wastes and their potential use for acid mine drainage remediation. Jurnal Natur Indonesia 12(2): 167-172.

Nyquist, J. \& Greger, M. 2003. MIMI-wetland plants for treatment of acid mine drainage. The MISTRA-programme MIMI. 35+p.

Paredez, D., Velez, M.E., Kuschk, P. \& Mueller, R.A. 2007. Effects of type of flow, plants and addition of organic carbon in the removal of zinc and chromium in small-scale model wetlands. In Movais, J.M. (Ed). Water Science and Technology. Wetland Systems for Water Pollution Control $X$. Selected papers from the $10^{\text {th }}$ IWA International Specialized Conference on Wetland Systems for Water Pollution Control, held at Lisbon, 23-29 September 2006. IWA Publishing. p: 199-205.

Sheoran, A.S. 2006. Performance of three aquatic plants species in bench-scale acid mine drainage wetland test cells. Mine Water Environ 25(1): 23-36.

Sheoran, A.S. 2004. Treatment of acid mine driange by constructed wetland: an ecological engineering approach. PhD Thesis, Jai Narain Vyas Univ, Jodhpur (India).

Skousen, J.G. \& Ziemkiewicz, P.F. 1996. Acid mine Drainage Control and Treatment. 2nd. Ed. West Virginia University and 
the National Mine Land Reclamation Center, Morgantown, Weset Virginia. 362+p.

Waybrant, K.R., Blowes, D.W. \& Ptacek, C.J. 1998. Selection of ractive mixtures for use in permeable reactive walls for treatment of mine drainage. Environ. Sci. Technol, 32: 19721979.

Weise, J.S. \& Weis, P. 2004. Metal uptake, transport, and release by wetland plants: implication for phytoremediation and restoration. Environmental International 39(5): 685-700.
Zagury, G.J., Neculita, C.M. \& Bussiere, B. 2007. Passive treatment of acid mine drainage in bioreactors: Short review, applications, and research needs. OttawaGe02007/ OttawaGéo2007: 1439-1446. http://www.polymtl.ca/envirogeremi/pdf/articles/CGS2007084.pdf On line on 16 April 2011. 